\title{
Memory in Contracts: The Experience of the EBRD (1991-2003)
}

\author{
Lionel Artige*- Rosella Nicolini ${ }^{\dagger \ddagger}$
}

January 2008

\begin{abstract}
The objective of this paper is to identify the role of memory in repeated contracts with moral hazard in financial intermediation. We use the database we have built containing the contracts signed by the European Bank for Reconstruction and Development EBRD between 1991 and 2003. Our framework is a standard setting of repeated moral hazard. After having controlled for the adverse selection component, we are able to prove that client reputation is the discrimination device according to which the bank fixes the amount of credit for the established clients. Our results unambiguously isolate the effect of memory in the bank's lending decisions.

Keywords: Financial Contracts, Incentives, Investment, Memory, Moral Hazard.

JEL Classification: D21, D82, G21, L14, P21.
\end{abstract}

${ }^{*}$ HEC- Department of Economics, Université de Liège. E-mail: lionel.artige@ulg.ac.be.

${ }^{\dagger}$ Corresponding author: Insitut d'Anàlisi Econòmica - CSIC, Campus de la Universitat Autònoma de Barcelona, 08193 Bellaterra (Barcelona), Spain. Ph. +34935806612, Fax +34935801452. E-mail: rosella.nicolini@iae.csic.es.

${ }^{\ddagger}$ We are grateful to Ramon Caminal, Ivan Fernandez Val, Inés Macho-Stadler, Martin Reiser for useful suggestions and discussions. Part of this research has been conducted while the second author was visiting the Department of Economics at Boston University. Any remaning errors are our own responsibility. R. Nicolini research is supported by Ramón y Cajal and by Barcelona Economics Program of XREA. Financial support from research grants 2005SGR00470 and SEJ2005-01427/ECON is acknowledged. 


\section{Introduction}

The optimal long-term contract in repeated moral hazard generally exhibits memory (Lambert 1983, Rogerson 1985 and Chiappori et alii 1994). The decisions made by the agent and the principal in the current period depend on past outcomes. With repeated contracts the principal is able to learn from the agent's past history and, hence, propose a long-term contract that internalizes this information over time. The benefit is that risk sharing is improved. A natural application of long-term contracting is in financial intermediation where banks and borrowers tend to maintain durable relationships and moral hazard is a key problem (Stiglitz and Weiss 1981, 1983). It has been proved that, thank to memory, a long-term credit contract benefits the borrower under the forms of lower interest rates and less collateral demands (Boot and Thakor 1994). However, other models predict that the duration of the bank-borrower relationship in fact increases the borrowing cost because its benefits also create for the borrower switching costs to start a new relationship with a competitor (Greenbaum et alii 1989 and Sharpe 1990). The benefits of the reduction in moral risk through memory would thus be offset by the market power gained by the bank. These conflicting predictions are reproduced by the empirical literature. Berger and Udell (1995) and Bodenhorn (2003) find a negative relationship between duration of the bank-borrower relationship and borrowing cost or collateral demands. Degryse and Van Cayseele (2000) find in contrast that the loan rate increases with the duration of the bankborrower relationship. Neither result is confirmed by other studies in which no statistically significant correlation obtains (Blackwell and Winters 1997, Petersen and Rajan 1994, Cole 1998 and Elsas and Krahnen 1998). This inconclusive empirical evidence illustrates that the borrowing cost may not only be a function of duration but also of other factors. It tends to increase with the amount of credit, the riskiness of the project and market power but tends to decrease with competition. In addition, banks use the borrowing cost to sort out borrowers and eliminate the ones with the highest probability of default. It is therefore an instrument to deal with both adverse selection and moral hazard (Stiglitz and Weiss 1981). The effect of memory is then difficult to capture.

We argue that the method used so far by the empirical literature is flawed. It pools all firms whatever the duration (or frequency or intensity) of the relationship with their bank, and estimates the effect of duration on the borrowing cost. The problem is that the borrowing cost can vary across firms not only because of the duration of the relationship but also as a result of the banks' screening policy to face adverse selection. In other words, this method is unable to disentangle the effects of adverse selection and moral hazard on the level of borrowing cost, which in turn prevents from identifying the effect of memory.

The present paper proposes a different empirical strategy to overcome this problem. First of all, like in the rest of the literature, we focus on one single bank to control for unobserved heterogeneity in lending policy. We built an original database from data made public by the London-based European Bank for Reconstruction and Development (EBRD) 
on all its investments in private and public firms during the first years of its existence (1991-2003). ${ }^{1}$ Second, our dataset allows us to split it into two subpopulations: firms having signed one single contract and firms having signed more than one contract. Then,we control for the adverse selection effect. In both subpopulations, the amount of lending and the type of contract set for each firm reflects the screening policy of the bank (as suggested in Gathak, 1999). In the subpopulation of the several-contracts firms there obviously exists for the bank information on the firms' past actions. The question is: will the bank use it? We run regressions in each of the two subpopulations. If the same results obtain, this means that the bank does not use the past history of its clients in designing contracts. Our results clearly show that it is not the case. The total project value of the fist signed contracts is neatly identified as the dominant individual fixed effect to design contracts for firms which signed more than one.

However, this result could be driven by the effect of competition. The bank could indeed charge lower borrowing cost to its long-term clients in order to prevent them from going to competitors. The specificity of the EBRD enables us to rule out this possibility. The EBRD was created in 1991 just after the Soviet Bloc had collapsed to assist the countries of this region in transforming their centrally planned economic systems into market economies. When it started its lending operations in 1991, the business environment of all these countries was characterized by large output fall, complete disorganization of production, macroeconomic and political instability and inadequate banking sector. This exceptional situation makes the EBRD experience an interesting natural experiment for two reasons. First, the management of risk had to be carried out in a very uncertain environment. The country risk was high due to the macroeconomic turmoil and all potential borrowers had no market experience neither creditworthiness history. Second, its decisions were not affected by competition because local banks were insolvent and foreign banks did not enter these risky markets in the early transition period. Moreover, the public shareholders of the EBRD assigned to the bank the mission to lead the financial flows to these countries and not to crowd out private investment flows. Therefore, the EBRD was in a situation of monopoly.

The control for the adverse selection effect and the monopolistic behavior of the EBRD offer ideal conditions to test memory in long-term credit contracting. Our estimations yield unambiguous results validating the predictions of contract theory on repeated moral hazard.

The remaining of the paper is organized as follows. Section 2 characterizes the model of the EBRD-client relationship. The data and descriptive statistics are presented in section 3. Section 4 examines the econometric analysis. Finally, section 5 concludes.

\footnotetext{
${ }^{1}$ Any local or foreign firm is eligible for EBRD financing
} 


\section{The EBRD-client relationship}

\subsection{The EBRD}

With a capital of 20 billion euros and owned by 61 countries and two intergovernmental institutions (the European Union and the European Investment Bank), the EBRD is a peculiar investment bank. Its main characteristics are the following:

- Unlike private investment banks, the EBRD has sovereign shareholders that do not receive dividends.

- Its investments are geographically restricted to the region of the former Soviet Bloc.

- Unlike the World Bank, the EBRD invests mainly in private enterprises. According to our calculations, the share of public clients between 1991 and 2003 does not exceed $12.5 \%$ of the total for a share of cumulated investment of $23 \%$.

- Its investments have to respect environmental standards.

- Its mandate stipulates that it must only work in countries that are committed to democratic principles. Nevertheless, some investments have been realized in certain countries that are far from being fully-fledged democracies.

On a theoretical point of view, we consider the objective function of the EBRD as identical as that of any investment bank. Its objective is to maximize profits from investment projects and do so by using all the instruments available on the financial markets to raise funds and protect its portfolio against risks. ${ }^{2}$ Figure 1 describes the EBRD performance over time.

However, its constraints are different. It must invest in a restricted geographic area precluding it to diversify its portfolio with investments in safer places in the rest of the world. Therefore, in this respect, the EBRD faces a harder constraint than any other investment bank. On the other hand, its sovereign shareholders guarantee it virtually against bankruptcy, which is far from the case for any other private investment bank. This feature together with its stable sovereign ownership allows the EBRD to raise funds at the best conditions and, simultaneously, face the high risks inherent to the investments in the region.

\footnotetext{
${ }^{2}$ In fact, the objectives of the EBRD are not totally identical to those of other investment banks. The EBRD aims at being a catalyst for financial institutions and wants to avoid crowding them out. In other words, the EBRD does not see other financial institutions as competitors. However, in the bank-client relationship, which is our concern in this paper, its objective is to maximize profits from its clients' projects, i.e., according to the EBRD's statement, to apply "sound banking principles".
} 


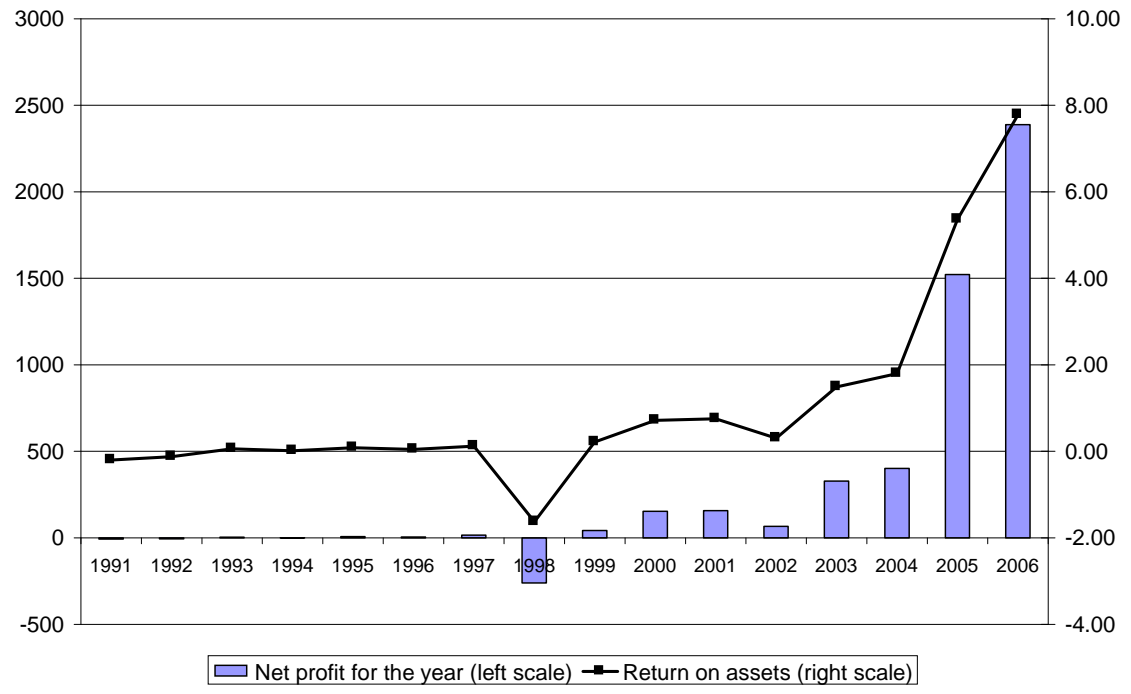

Figure 1: EBRD performance (€ million) (Source: EBRD, Calculus: authors)

\subsection{The theoretical model}

Our theoretical model aims at designing an optimal contract signed under moral hazard conditions (as in Lambert (1983) and Chiappori-Macho Stadler (1990)). First, we consider one stage game corresponding to a contract running for one period. The bank and its client agree on signing the contract; then, the bank finances the firm which realizes the investment and pays back the loan (plus interests) to the bank. ${ }^{3}$ Second, we consider a contract that lasts for two periods. In this two-stage game, the bank grants a loan in two distinct periods. After the signature of the contract by both parties, the bank delivers a part of the loan to the firm that starts the investment. At the end of the first period, the bank observes the results of the firm's investment and decides at which condition to lend the remaining part of the loan. We therefore assume that the contract signed in the first period is binding: the bank has to give the second part of the loan to the firm but can change the conditions if the firm does not behave well in the first period. It is in this second type of contract that the incompleteness problem arises and the role of memory turns out to be fundamental.

\footnotetext{
${ }^{3}$ In this section, for sake of simplicity, we identify as loan any kind of credit contract the bank can grant.
} 


\subsubsection{Simple principal-agent model}

The most simple credit line model involving a principal-agent relationship is structured as followed: the bank (the principal) lends an amount of money $M$ to the firm (the agent) and asks a refund of $R$ if the firm's investment is successful, a refund $\underline{R}$ otherwise $(R>\underline{R})$. The

firm uses $M$ to realize an investment. If the firm provides the good effort $H$, the return of the investment is $I$ and it has to pay back $R$ to the bank. If it provides the low effort $L$, the return of the investment is $\underline{I}$ and it has to pay back $R$. The benefit is assumed to be higher when the firm provides a high effort : $(I-R)>(\underline{I}-\underline{R})>0$. However, the higher effort costs $V_{H}$ to the firm. It is assumed that the application process for a loan costs a strictly positive amount $C$ to the firm. If the bank turns down the application the firm incurs the loss $C$.If the bank accepts the application, it sets the conditions of the loan and the firm has to agree with them. If the firm disagrees it has to pay $C .{ }^{4}$ The bank is assumed to be risk neutral and the firm risk neutral with a limited liability. The liability condition ensures that the investment return is sufficient to cover the capital that the firm has to pay back plus the initial sunk cost $C$. The task of the bank is then to choose the right incentive to induce the firm to provide the maximum effort in order to make both the investment successful and yield the highest return (and hence the highest refund for the bank). The investment will be successful with probability $P_{i}$ (for $i=H, L$ ) and will fail with probability $\underline{P_{i}}$ (for $i=H, L)$.

In the one-stage contract, the bank faces the following maximization program:

$$
\begin{gathered}
\max _{R, \underline{R}} P_{H}(R-M)+\underline{P_{H}}(\underline{R}-M) \\
P_{H}(I-R)+\underline{P_{H}}(\underline{I}-\underline{R})-C-V_{H} \geq 0, \\
\left(P_{H}-P_{L}\right)[(I-\underline{I})-(R-\underline{R})] \geq V_{H}, \\
\text { and } I \geq R+C, \underline{I} \geq \underline{R}+C,
\end{gathered}
$$

where (1) is the utility function of the bank, inequality (2) is the participation constraint of the firm and inequality (3) is the incentive compatibility constraint of the firm and inequalities (4) are the limited liability conditions of the firm.

Given the bank's utility function, we are interested in defining the optimal contract under which the firm chooses the high effort such as to obtain $I$. Since the objective

\footnotetext{
${ }^{4}$ According to the mechanism of the model it is not rational for the firm to reject the application when accepted by the bank.
} 
function is linear in $R$, the solution of the problem is given by substituting constraint (3) into (2).

For $P_{H}>P_{L}$ we obtain the following equilibrium results :

$$
R=I-C-V_{H}\left(\frac{\underline{P_{L}}}{P_{H}-P_{L}}\right), \underline{R}=\underline{I}-C+V_{H}\left(\frac{\underline{P_{L}}}{P_{H}-P_{L}}\right) .
$$

These are the two solutions for the existence of a separating equilibrium that guarantees the existence of an optimal contract. Such a contract allows the bank to distinguish the two possible behaviors of the firm and reward them in a different way in order to incite the firm to choose the higher effort. Nevertheless, the two solutions (5) must satisfy the liability conditions (4).

Since the bank wants to force the firm to make the maximum effort, as in a standard moral hazard problem (see Macho Stadler and Pérez Castrillo, 2000), the principal (the bank) has to incur a cost which implies reducing its profits in comparison to a situation without moral hazard. In order to make the firm behave well, the bank offers the following contract which turns out to be Pareto optimal :

$$
R^{*}=I-C-V_{H}\left(\frac{1}{P_{H}-P_{L}}\right), \underline{R^{*}}=\underline{I}-C .
$$

If the investment fails the bank extracts all the surplus of the firm. If it is successful the firm receives a premium reducing the profits of the bank. This threat is credible since the firm has an incentive to provide the higher effort.

\subsection{The two-period model: the role of the memory}

In the previous section the amount of the loan, once accepted by the bank, was delivered to the firm all at once. In this section, we assume that it is paid in two steps. The problem faced by the bank therefore becomes dynamic. At the beginning of the first period, the bank determines the total amount of the loan and delivers the first part to the firm. In the second period, it always delivers the second part but can change the conditions at which the loan must be paid back.

In a two period loan, two scenarios are possible depending on whether the two stages are independent or not. If the stages are independent, the final result is the sum of the results of two one-stage games. Such a contract is nevertheless an incomplete one. Chiappori et al. (1994) prove that the long-term relationship can outperform a succession of day by day agreements if the role of memory is taken into account. To obtain this result, the principal's objective function must be time-separable and the current behavior must affect the probability of the current outcome. Under these assumptions the bank can write a 
long-term renegotiation proof contract by adapting the terms of the contract in the second period with respect to the return of the firm's investment in the first period. Therefore, the bank keeps in memory the return of the firm's first-period investment. The structure of such a contract is optimal; neither the principal (bank) nor the agent (the firm) has an incentive to deviate and sign a new contract.

In order to formalize memory in our setting, it is assumed that the utility function of the bank is time-separable and the profits of the second period are related to the outcome of the first one. ${ }^{5}$ The firm has to pay back $R_{2}$ if the investment is successful in both periods, $\underline{R_{2}}$ if it is a failure in both periods, $R_{2}^{\prime}$ if it is a success in the first period, but a failure in the second one, and $R_{2}^{\prime}$ if it is a failure in the first period and a success in the second one. We define four returns of the investment for the firm in the second period as $I_{2}$ (for success in both periods), $I_{2}$ (for failure in both periods), $I_{2}^{\prime}$ (for failure in the first period and success in the second one), and $I_{2}^{\prime}$ (for success in the first period and failure in the second one). We also assume that the bank commits to give the same amount of money to the firm both in case of failure and success in the first period. As before, we impose limited liability (conditions 12). All the constraints take the role of memory into account. In the second period firms do not have to pay the $\operatorname{cost} C$ as in the first period but the bank has to build a device to force the firm to behave well in both periods. This device is represented by a premium $\Delta$ which is a debt reduction in period two if the firm behaves well in period one or a debt increase otherwise. Finally, it is assume that, for a given level of effort, the probability of failure or success of an investment is the same in both periods.

Given all the previous assumptions the problem is defined as follows:

$$
\begin{aligned}
\max _{R_{2}, \underline{R_{2}}, R_{2}^{\prime}, \underline{R_{2}^{\prime}}} & P_{H}\left[P_{H}\left(R_{2}-M\right)+\underline{P_{H}}\left(\underline{R_{2}^{\prime}}-M\right)\right]+\underline{P_{H}}\left[P_{H}\left(R_{2}^{\prime}-M\right)+\underline{P_{H}}\left(\underline{R_{2}^{\prime}}-M\right)\right] \\
& P_{H}\left(I_{2}-R_{2}\right)+\underline{P_{H}}\left(\underline{I_{2}^{\prime}}-\underline{R_{2}^{\prime}}\right)-V_{H} \geq 0, \\
& P_{H}\left(I_{2}^{\prime}-R_{2}^{\prime}\right)+\underline{P_{H}}\left(\underline{I_{2}}-\underline{R_{2}}\right)-V_{H} \geq 0, \\
& \left(P_{H}-P_{L}\right)\left[\left(I_{2}-I_{2}^{\prime}\right)-\left(R_{2}-\underline{R_{2}^{\prime}}\right)\right] \geq V_{H}, \\
& \left(P_{H}-P_{L}\right)\left[\left(I_{2}^{\prime}-\underline{I_{2}}\right)-\left(R_{2}^{\prime}-\underline{R_{2}}\right)\right] \geq V_{H},
\end{aligned}
$$

\footnotetext{
${ }^{5}$ In the second period, the bank lends to the firm the amount of money originally stipulated in the contract. The bank can only change the pay-back conditions of the second-period part of the loan according to the behavior of the firm in the first period.
} 


$$
\text { and } R_{2} \leq I_{2}-\Delta-C, \underline{R_{2}} \leq \underline{I_{2}}+\Delta-C, R_{2}^{\prime} \leq I_{2}^{\prime}-\Delta-C, \underline{R_{2}^{\prime}} \leq \underline{I_{2}^{\prime}}+\Delta-C,
$$

where (7) is the utility function of the bank when there are two periods. The number of the constraints increases with the number of the additional variables we introduce. Inequalities (8), (9), (10), and (11) are respectively the new participation and the incentive compatibility constraints. As mentioned earlier, conditions (12) are the limited liability constraints.

The objective function of the bank is linear in the variables $R_{2}, \underline{R_{2}}, R_{2}^{\prime}, \underline{R_{2}^{\prime}}$ and the constraints are linearly independent.

We solve the problem as previously with respect to the corresponding constraints and we obtain for $P_{H}>P_{L}$ :

$$
\begin{gathered}
\underline{R_{2}^{\prime}}=\underline{I_{2}^{\prime}}+V_{H}\left(\frac{\underline{P_{L}}}{P_{H}-P_{L}}\right), R_{2}^{\prime}=I_{2}^{\prime}-V_{H}\left(\frac{P_{L}}{P_{H}-P_{L}}\right), \\
R_{2}=I_{2}-V_{H}\left(\frac{P_{L}}{P_{H}-P_{L}}\right), \underline{R_{2}}=\underline{I_{2}}+V_{H}\left(\frac{\underline{P_{L}}}{P_{H}-P_{L}}\right) .
\end{gathered}
$$

By comparing these results with the liability constraints we obtain four different optimal values of the amount of money the firm has to pay back to the bank corresponding to four different situations. Hence, the optimal equilibrium values for the renegotiation proof contracts are :

$\underline{R_{2}^{\prime *}}=\underline{I_{2}^{\prime}}+\Delta, R_{2}^{\prime *}=I_{2}^{\prime}-V_{H}\left(\frac{1}{P_{H}-P_{L}}\right)+\Delta, R_{2}^{*}=I_{2}^{\prime}-V_{H}\left(\frac{1}{P_{H}-P_{L}}\right)-\Delta, \underline{R_{2}^{*}}=\underline{I_{2}}-\Delta$

The optimal strategy of the bank in the second period is to propose four different contracts to the firm according to the results obtained in the first period. These contrats are Pareto optimal contracts since no agent has an incentive to deviate from the given strategy. Hence, this set of solutions are four renegotiation proof contracts, and no profitable deviating behavior is allowed. Therefore, these four different contracts that describe the optimal strategy of the bank when it values the past behavior of a client.

\section{$3 \quad$ Data and descriptive statistics}

We have built an original database from data made public by the EBRD over the years. Our database includes 1788 financial contracts signed by the bank with private and public clients 
from 1991 to 2003. It contains information on the identity of the clients, the amount of the contract in ECU/Euros, the value of the investment project, the sector of investment, the nationality of the client, the year of the signature of the contract, the type of contract (loan, share, equity and guarantee), and other characteristics (old clients, private/public, macroprograms...). In this section we present a brief overview of the contents of our database and we discuss the most relevant results of a simple descriptive analysis.

\subsection{The contracts}

The number of contracts and the amount of the annual investments were very low at the beginning of the transition process (see Figure 2 and Figure 3). The EBRD was underusing its capital which was subject to criticism among the shareholders and commentators. This underuse was principally due, to a large extent, of the severe macroeconomic downturn that the entire region suffered.

After these initial difficulties, the target of the bank was to strongly increase the volume of the portfolio. The recovery of most of the countries in the region helped the EBRD in increasingly signing contracts and make sizable profits from 1999 on.

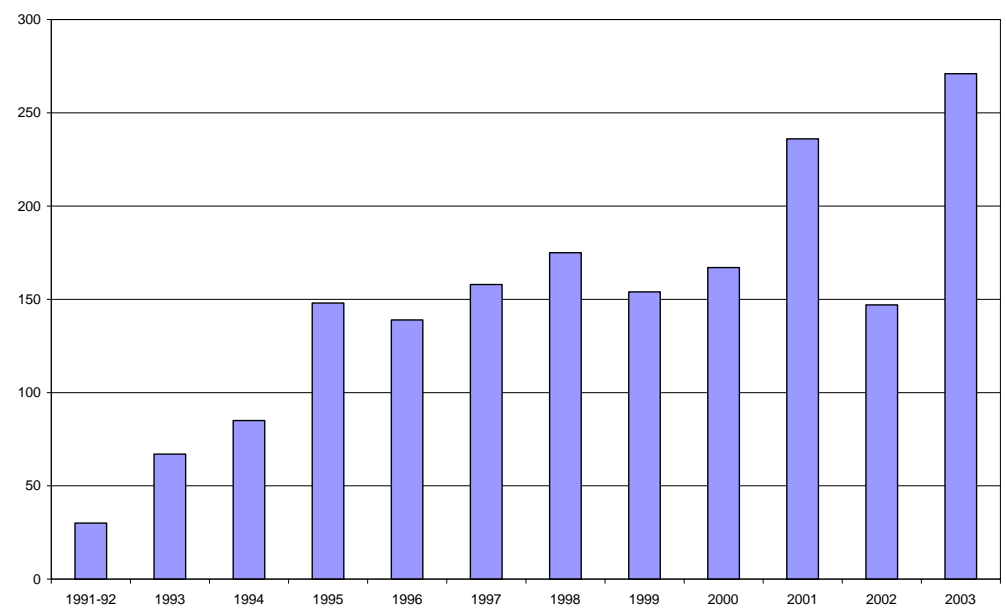

Figure 2: Number of contracts signed by the EBRD between 1991-2003

The average EBRD investment has been remarkably stable with a slight downward trend in the most recent years (see Figure 4).

According to the information available on the EBRD website, the bank designed different kinds of contracts. They all represent the financial instruments by which the bank 


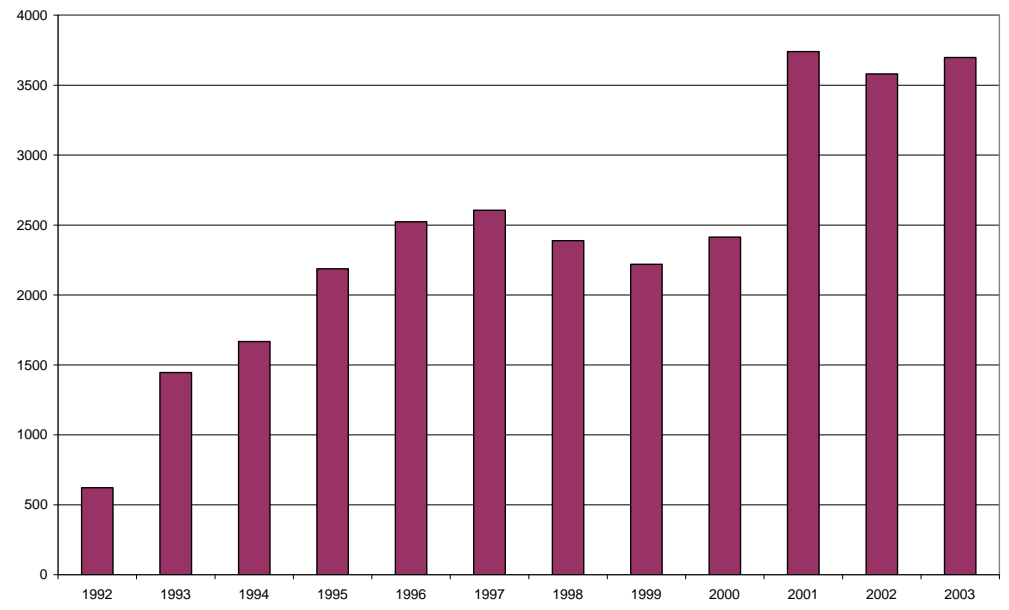

Figure 3: EBRD Investments by year $(\mathrm{ECU} / €$ million $)$

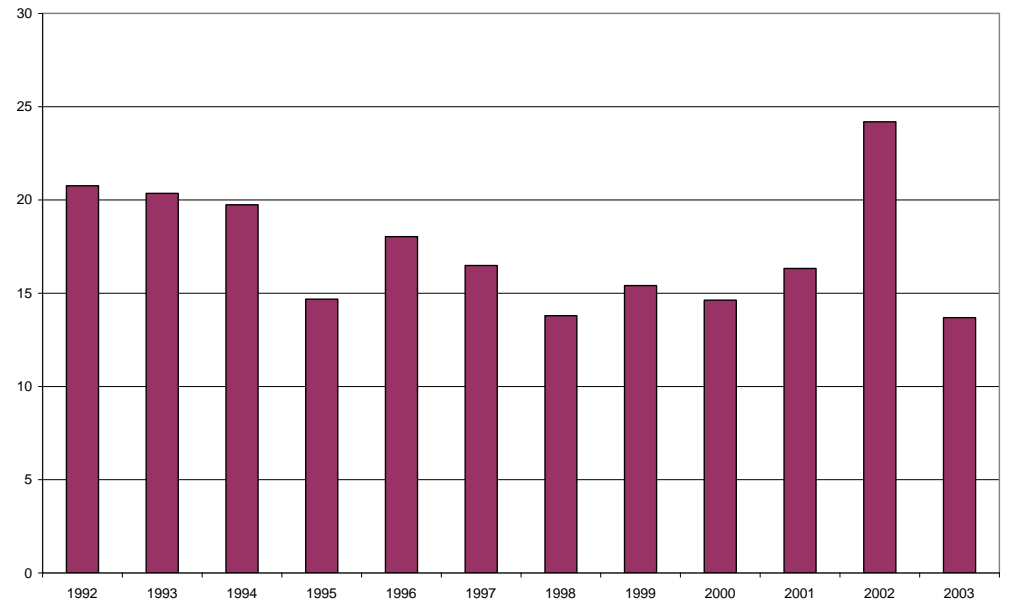

Figure 4: Average EBRD investment by year (ECU/€ million) 
participates in the realization of the investment project proposed by the borrower. These contracts not only differ in the maturity of the credits but also in other characteristics that we will discuss below. First, in Table 1 we provide a general overview of the different kind of contracts signed by the bank and their frequency:

[Table 1 about here]

Three main categories of credit instruments can be distinguished: loan, guarantee, and share and equity contracts. Loans have been the most used financial contract by the EBRD between 1991 and 2003 (Figure 5).

A loan is generally considered as a short-term contract, lasting 5 years on average, and tailored as to meet the particular requirements of the project. The credit risk is usually taken by the bank or partially syndicated to the market. A loan may be securitized by a borrower's asset and/or converted into shares or be equity-linked. The second important category of contracts includes share and equity. Share-type contracts were mainly signed at the beginning of the EBRD's activity while equity contracts represent a large category of financial contracts including share contracts. An equity investment can be undertaken in various forms, including subscription to ordinary shares. When the EBRD takes an equity stake it expects an appropriate return on its investment. The bank usually sells its equity investment on a non-recourse base, has a clear exit strategy and only takes a minority position. ${ }^{6}$ The third category of credit instruments refers to guarantee contracts. They have been used mainly at the end of the period. By this type of contract, the bank helps borrowers in gaining access to financial sources through the provision of guarantees (EBRD, 1999).

Table 2 and 3 show descriptive statistics on the total values of projects that have been selected by the EBRD and the parts (bank financing) that were effectively financed. In most of accepted projects, the EBRD is not the unique source of fund. The statistic information is given for the total sample and two parts of it, at the outset of transition (1993-1995) and at the end of the sample period (2000-2003). The total project value of loans is always higher than that of shares, but both have decreased over time. The median bank financing in loan contracts has been unchanged over time while it has declined in share contracts.

Figure 6 compares the fraction of the total project value financed by EBRD between share and loan contracts. This fraction increases proportionally with the total project value but the increase is more pronunced for shares than for loans. As a shareholder the bank can control the managment of the firm which implies the reduction of the uncertainty associated to the imperfect information about the firm behavior. The bank tends to augment its participation with the size of the project value in share contracts in order to protect itself against the risk. As for loans, the collateral insures a proper control of the risk.

\footnotetext{
${ }^{6}$ Equity is considered as a non contingent contract.
} 


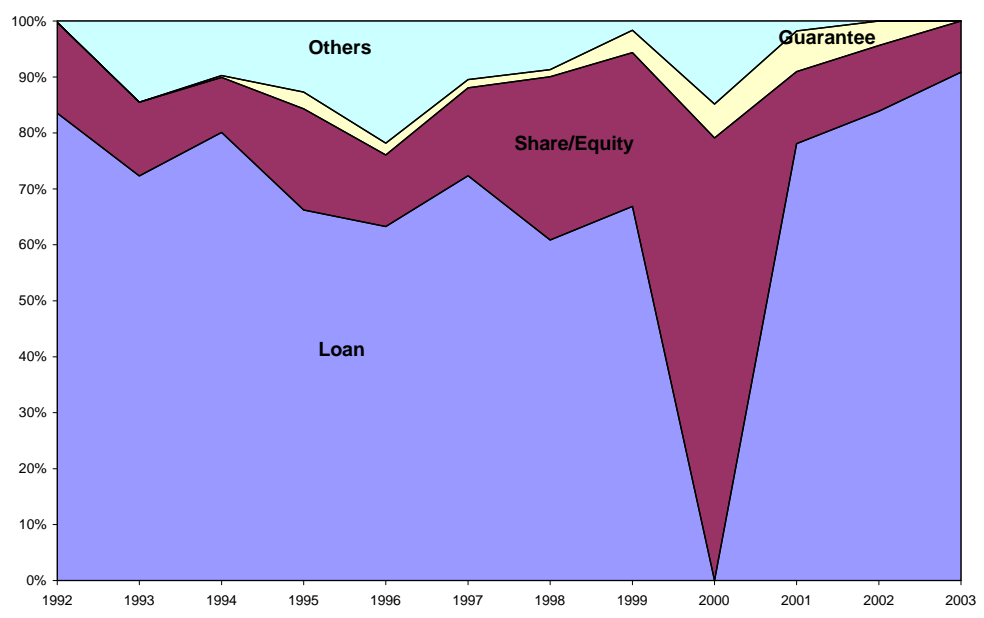

Figure 5: Financial contracts by type in percentage by year

[Table 2 about here] [Table 3 about here]

We also split the sample into two subgroups of firms: ${ }^{7}$ a first group with firms having obtained one credit over the sample period (around 1270 firms) and a second group with those having signed more than one contract (around 100 firms). Table 4 and 5 show data for single-contract and several-contract firms respectively. The median bank financing part for several-contract firms is always more important than for single-contract firms. These differences may be associated to reputation premia.

[Table 4 about here]

[Table 5 about here]

\subsection{Countries and sectors}

There are two criteria that can account for the geographical distribution of contracts between 1991-2003: market size (population size or income per-capita), and political regime.

Figure 6 and Figure 7 show the geographical distribution of the EBRD investments in cumulated terms by country and per-capita by country.

\footnotetext{
${ }^{7}$ This split of the sample will be essential to test the role of the memory on the bank behavior in the econometric exercise.
} 


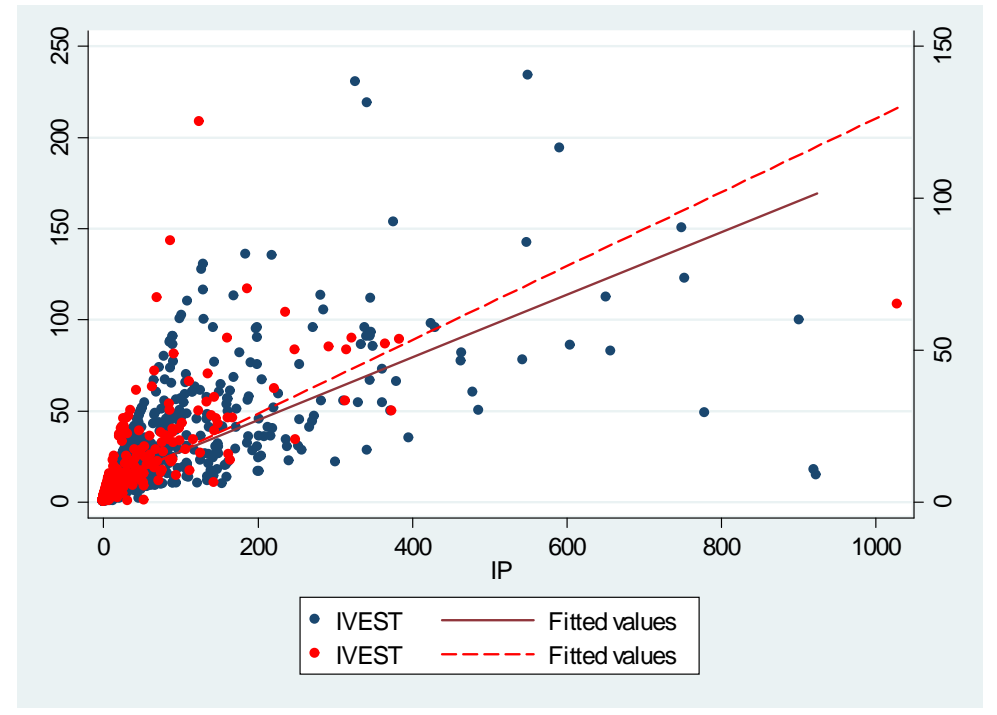

Figure 6: Fraction of EBRD financing in share and loan contracts (red points and dashed line for shares, and blu points and line stand for loans)

Russia has received more credits than any other country in the region over the period followed by the Eastern European countries, and then by the Central Asian countries.The latter countries not only offer poor business climate and also non democratic institutions. In terms of the cumulated amount of investments per-capita, the ranking among the destination countries is substantially reversed in the upper half of the distribution. The Central European countries, which are the most developped countries of the sample and leading the transition process, have received the largest per-capita financing (around 300 thousand Euro for Slovenia, Croatia and Estonia) while the Central Asia countries still lag very much behind. According to this second criterion, Russia moves down to the lower half of the distribution.

[Table 6 about here]

We split the distribution into three sub-periods (1991-1995, 1996-1999 and 2000-2003). Table 6 shows that at beginning of the transition process almost half of the investments went to the earlier starters, Central Europe and the Baltic states. Then their share reduced to roughly one third of the total. Along with the transition process, Russia received and increasing part of the the EBRD investments and its share has remained stable. SouthEastern Europe has seen a progressive increase in its share of the EBRD investments over the period. The relative share of Eastern Europe and the Caucasus has decreased. Finally, 


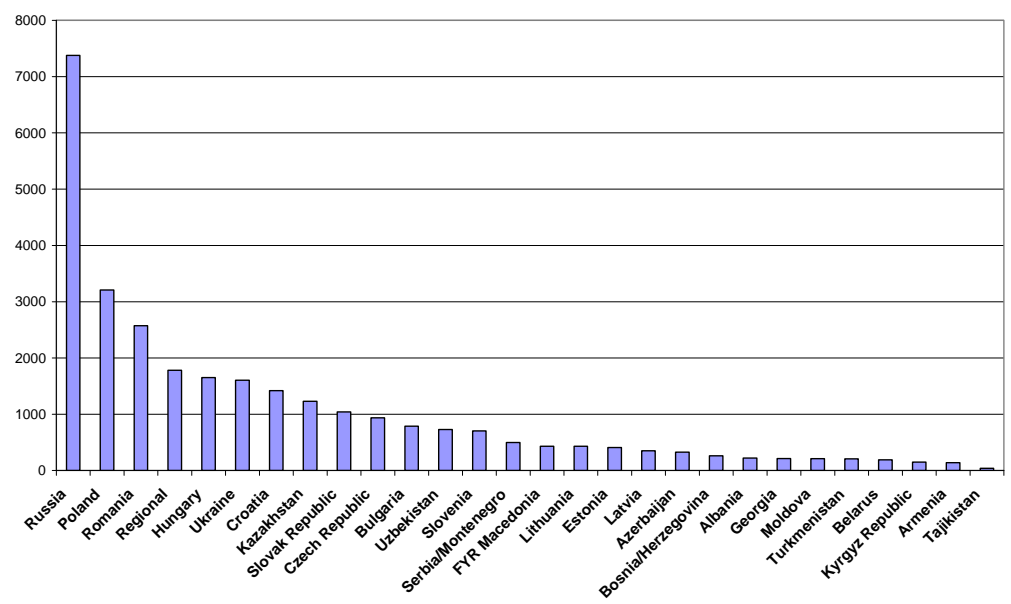

Figure 7: Cumulated EBRD investment by country ( $€$ million)

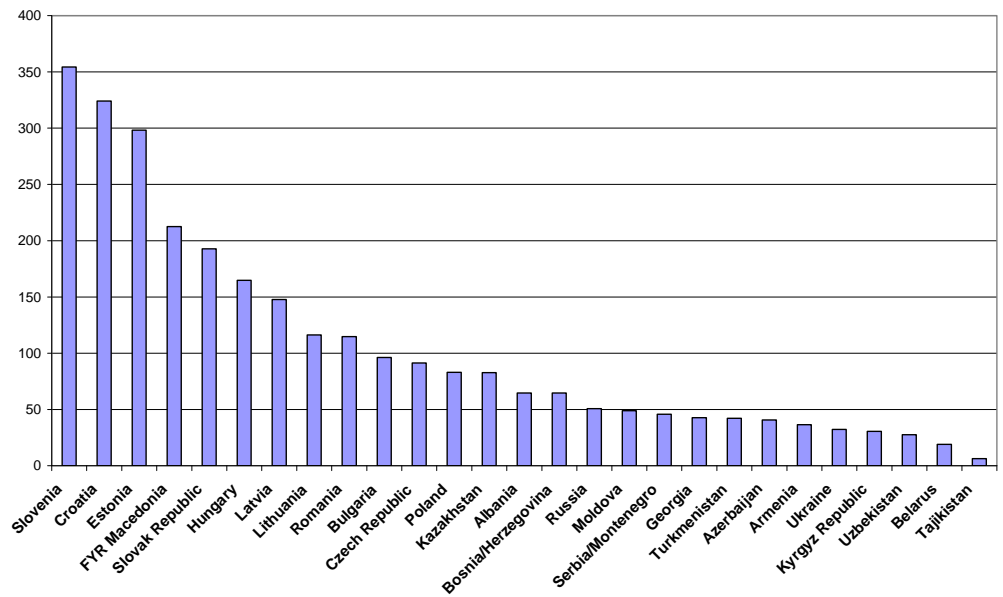

Figure 8: Cumulated EBRD investments per capita by country ( $€$ thousands) 
the Central Asian countries reached a noticeable share between 1996-1999 which fell by half in the last period.

\section{[Table 7 about here]}

As for the distribution by sector (Table 7), at the beginning of the transtion, most of the investments of the EBRD went to Finance, Telecom, Oil/Gas/Natural Resources and the group of Other sectors. The objective was to finance infrastructure and the restructuring of the banking and the manufacturing sectors. Thereafter, the focus of the bank switched to the financing of the creation of small and medium entreprises (SMEs),

\section{Econometric Analysis: model and results}

The EBRD selects one of 13 different available contracts (see Table 1) when deciding to finance the investment project of a firm. The selected one should be the contract which reduces the asymmetric information as much as possible between the principal and the agent.

The objective of the econometric analysis is to identify the level of heterogeneity which enables the bank to discriminate among the firms and select the contract that will incite them to behave well. In particular, we want to verify if the bank modifies its behavior when it signs several contracts with the same firm over time. If it does, as proved by Chiappori et alii. (1994), this means that the bank uses the historical information (memory) about the firm to adjust the financing conditions in order to maximize its profits.

To do so, first, we proceed by splitting the whole sample into two subsamples: onecontract firms and several-contract firms. The latter subsample includes historical information on the firms and we want to check if the bank uses it. This is the way to control for the role of memory. We apply the same econometric specification to both subsamples but allowing for different specifications of the same fixed effects. By comparing the results and checking for robustness we identify the role of memory.

\subsection{Econometric model}

Equations 6 and15 describe respectively the one-period and several period contracts. These equations written in a reduced form as:

$$
R_{i}=I_{i}+\underline{D} \text { where } i=\text { firm }
$$

The amount of the money the firm $i$ is expected to pay back $\left(R_{i}\right)$ is proportional to the return of the investment $\left(I_{i}\right)$ plus a vector of other variables $(\underline{D})$ representing the effort made by the firm in the realization of the project, its cost, and other conditions affecting 
the success of an investment. The two former variables are liked to the firms' behavior and the latter is associated with the uncertainty conditions in the host markets. As expressed by equation (15) when the firm sign several contract with the bank, the vector $(D)$ includes the premium granted to the firm receives whenever it behaves well.

In our database, we do not have data for all the variables we have describes. Therefore, we need to define proxies for some of them. Among them is the variable $R_{i}$, which is the capital plus interests that must be paid back to the bank. We have data on capital $\left(C_{i}\right)$ but not on the interest rate set by the bank for confidenciality reasons. In a simple interest contract the refund is equal:

$$
R_{i}=C_{i}+m_{i}\left(\frac{C_{i} i_{i}}{100}\right)=C_{i}\left(1+\frac{m_{i} i_{i}}{100}\right),
$$

where $C_{i}$ is the capital borrowed by the firm, $m_{i}$ is the maturity of the credit (in number of years) and $i_{i}$ is the nominal annual interest rate charged by the bank. Replacing this expression in equation (16) we obtain

$$
C_{i}\left(1+\frac{m_{i} i_{i}}{100}\right)=I_{i}+\underline{D} .
$$

As a result, the capital $C_{i}$ can be expressed as function of $\left(I_{i}, m_{i} i_{i}, \underline{D)}\right.$ such as:

$$
C_{i}=\frac{I_{i}+\underline{D}}{\left(1+\frac{m_{i} i_{i}}{100}\right)}=f\left(I_{i}, m_{i} i_{i}, \underline{D)}\right.
$$

where $\frac{\delta f}{\delta I_{i}}>0$,i.e. the size of the credit increases with the return of the investment, and $\frac{\delta f}{\delta m_{i} i_{i}}<0$, i.e. the size of the credit decreases with total interests.

In equation (16), the variables for which we have data are $C_{i}(I V)$ and the vector $(\underline{D})$. The vector of other variables $(\underline{D})$, includes a mesure of income level of the host market (GDP per-capita), an indicator for political institutions (degree of democray, Dem ), Time dummies and, finally, a dummy for public institutions as clients.

For the others we need to find proxies. The return of the investment $\left(I_{i}\right)$ can be approximated for a solvent firm by the value of the investment ( $I P$, available in the database). This is the minimum level of return of any succesfull investment.

As for total interest $m_{i} i_{i}$, we make three assumptions. First, we consider that the minimum cost of borrowing in the market is the cost of a loan, and second that the bank will apply this rate to any other kind of contract it signs. Third, the maturity of a credit is different for each category of contract. Finally, we know that the interest rate charged by the EBRD is equal to Libor plus a margin $\left(r_{i}\right)$. Since we do not have data on the margin, we can express it as a percentage $\left(\alpha_{i}\right)$ of Libor :

$$
m_{i} i_{i}=m_{i}\left(\text { Libor }+r_{i}\right)=m_{i}\left(\text { Libor }+\alpha_{i} \text { Libor }\right)
$$


If we express the margin as a percentage of Libor, the previous expression can be written as:

$$
m_{i} i_{i}=\left(1+\alpha_{i}\right) m_{i}(\text { Libor })=\gamma_{i} m_{i}(\text { Libor }) \text { where } \gamma_{i}=\left(1+\alpha_{i}\right)
$$

The variable $\gamma_{i}$ is time-invariant because the conditions of the contract are fixed at the time of the signature.

Therefore, under all these assumptions, we can approximate the value of $R_{i}$.

[Box 1 about here]

The specification used for the estimation is derives from equation (17) and can be written as:

$$
\begin{aligned}
& I V_{i j y t} \equiv C_{i}=f\left(I_{i}, m_{i} i_{i}, \underline{D)} \Rightarrow\right. \\
& I V_{i j y t}=f\left(I_{i}, m_{i} i_{i}, \underline{D)}=\beta_{1}+\beta_{2} I P_{i j y t}+\beta_{3} D e m_{j t}+\beta_{4} G D P_{j t}+\beta_{5} D I_{j}-\right. \\
& \beta_{7} m_{i} \gamma_{i}\left(\text { Libor }_{t}\right)+\beta_{7} \text { Year }_{t}+\beta_{8} \text { Sector }_{y}+\beta_{9} \text { Dem }_{j t} * \text { Year }_{t}+\varepsilon
\end{aligned}
$$

where $i=$ firm, $j=$ country, $y=$ sector, $t=$ time. The description of the variables is given in Box 1.

[Table 8 about here]

Table 8 gives descriptive statistics for some of these variables for the overall sample period and for two years: 1993 and 2003. The dependent variable is the amount of the credit $(I V)$ granted by the EBRD. This is one of the distinguishing characteristics of a contract when the bank proposes it (as discussed in Stiglitz and Weiss, 1981). It embeds the screening process that takes place across clients.

The measure of political institutions is taken from Polity IV project (2007). It is an index varying between 0 (for an absolute autocracy) and 10 (for a fully fladged demcracy). The Polity project assigns its scores according to three criterias:

1. Institutions that allow citizens to express their preferences concerning policies and leaders,

2. Institutional limits on the exercise of power by the executive,

3. Guarantee of daily liberties to citizens in their daily life.

In our sample this index declines over time because the EBRD financed democracies of Central and Eastern Europe at the beginning of the transition and later started to finance autocratic countries from Central Asia.

The variation of Libor (London Interbank Offered Rate) corresponds to the historical variations due to changes in the credit market condition. 
According to our theoretical model and the assumptions we made, we expect that all independent variables in equation (18) but Libor has a positive sign. An increase in Libor implies a decrase of the amount of credit.

In order to test the level of individual heterogeneity we apply the technique of pooled OLS versus fixed effects. ${ }^{8}$ In all the contracts signed by EBRD there is one individual feature which is time invariant: $m_{i} \gamma_{i}$. We will treat it as an individual fixed effect.

We will identify it by applying four different measures: ct2, Ct2PPRR, Ct2IPPRR, IPPPPRR.

By running regression with ct 2 as individual fixed effects, we do not include any historical information for the firms. When we introduce historical information on individual firms (by $P P R R$ variable), it is possible to observe whether the past of firms affects the conditions of the contract proposed by the bank. If it does, we can conclude that the bank memorizes the past information and uses it to adjust the conditions of the next contracts for each individual firm.

\subsection{Results}

Our database contains all contracts signed by the bank over the period 1991-2003. We split it into two groups: one-contract firms and several-contract firms. In order to test the role of memory, we run regressions separately for each group of firms.

We proceed first by assessing if the fixed effect model should be preferred to the pooled OLS (with F-test) and to random effect model (with Hausman's test). In all the regressions we control for heteroskedasticity by applying the White correction. Then, we test the different measures of induvidual fixed effects.

\subsubsection{One-contract firms}

This sample includes 1269 contracts. Since, to each contract corresponds a firm we do not have historical information of the firms. Therefore we can only test one measure of individual fixed effects (ct2). This is a qualitative variable that identifies each type of the 13 contracts.

[Table 9 about here]

[Table 10 about here]

The results of the F-test and the Hausman test show that the fixed effect model should be preferred to the pooled and random effects model (Tables 9 and 10). In addition, the fraction of the variance due to fixed effects $(\rho)$ is particularly high $(0.70)$. The estimates of

\footnotetext{
${ }^{8}$ The econometric estimations have been computed with Stata 9.0 package.
} 
$\rho$ suggests that almost three quarters of the variation in the amount of a credit is related to the different types of contracts (Baltagi, 2005 and Baum, 2006).

In the fixed effect estimations, the coefficients of all the explanatory variables (when they are statistically significant) display the expected sign.

The repayment capacity of the firm is always highly significant.

All dummy variables are always statistically significant. The public identity of a client turns out to be important for the bank because a public client can,perhaps, be considered by the bank as less risky than a private one. The significance of interaction term between democracy (DEM) and the time dummy means the more democratic a country is over time the larger is the size of the credit offered by the bank. This result either tends to confirm the official claim that the EBRD promotes democratic institutions in transition countries or means that a country moving to democracy (over time) offers more profitable investment opportunities.

To sum up, for the one-contract firms the individual fixed effects by type of contract turn out to be a good measure to identify individual heterogeneity. Each contract signed by the bank is granted according to the individual characteristic of the client.

\subsubsection{Several-contract firms}

This sample includes 346 contracts. Now, to a firm corresponds more than one contract. Therefore, we have historical information on each individual firm and we can control for it. Given this characteristic, we want to check whether the individual heterogeneity we indentified in the previous sample holds in the present sample. Thus, we repeat the previous entire exercise for this sample. In order to control for heteroskedasticity we alternatively apply the White and the cluster correction. The cluster correction is important for controlling the autocorrelation in the residuals because each firm appears more than once in the sample.

[Table 11 about here]

[Table 12 about here]

The previous exercise for this sample yields a first important result: individual fixed effects by type of contract do not capture the individual heterogeneity (Table 11 and 12).

First, the F-test is weakly significant or insignificant while the Hausman's strongly rejects the random effect model. As a result we conclude that the model with individual fixed effects by type of contract is not robust estimation technique for this sample. This conclusion is reinforced by the low level of $\rho$ (0.07-0.12) of these estimations.

Therefore, we need to look for other measures of individual fixed effects for controlling individual heterogeneity. To this end we will exploit the historical information included in this sample by testing the three remaining measures of individual fixed effects previously defined: Ct2PPRR, Ct2IPPRR, IPPPPRR. Each of these measures contains this 
historical information because it takes into account the information associated to the first contract signed by each firm $(P P R R)$. The variable IPPPPRR represents the project value of the first contract, the variable $C t 2 P P R R$ is the type of the first signed contract and $C t 2 I P P R R$ is the combination among the two others. The present exercise yields the second important result of the paper: the individual fixed effects by the project value of the first contract accounts for individual heterogeneity in this sample.

[Table 13 about here]

[Table 14 about here]

[Table 15 about here]

The F-test and Hausman's test (Table13, Table 14 and Table 15) imply that the fixedeffect model is always preferred. Whenever the project value of the first contract is included in the individual fixed effects the value of $\rho$ goes up strongly. However, when we only consider the type of the first contract, the level of $\rho$ remains low.

In addition, the project value $(I P)$ and Libor are always statistically significant and have the expected sign. We introduce an additional variable (IPDSY) representing the case that a firm receives more than one contract in the same year. In this sample we need to control for these observations because they cannot be associated to a fully memory effect. In the meanwhile, we cannot drop them from the sample because of the nature of the bankclient relationship. We obtain a positive and always statistical significant coefficient. This result can be interpreted as an evidence that the bank has a further device to control better the riskness of the investments proposed by these firms.

Regarding the dummy variables, we obtain the same results as those of the one-contract firm sample expect for the dummy of public client. In the present sample, this dummy is never significant, which reinforces our conclusions that the bank's behavior relies strongly on memory. In the previous sample, the absence of historical information was offset by the reliance on the other variables, notably by the identity of public client.

Memory allows the bank to discriminate firms according to their individual historical characteristics and offer tailored contracts to better control risk. As discrimination effect, it can be observed that the number of groups inside this sub-sample increases from 8 to 90/94 thank to the memory effect.

\section{Conclusions}

Contract theory has proved that the optimal contract generally exhibits memory in repeated contracts with moral hazard. It has turned out to be difficult to clearly identify it in the empirical literature on long-term contracting in financial intermediation. Considering that the method used so far in this literature is flawed, we proposed in this paper an alternative 
empirical method based on the separation of observations between short-term and long-term contracts. We argue that this procedure is required to control for the adverse selection effect in the bank's lending policy. Nevertheless this is not sufficient. The effect of memory on moral hazard can be affected by the competition effect in the banking industry making it hard to isolate. The dataset we built from the European Bank for Reconstruction and Development allows for achieving it. The EBRD has been in a situation of monopoly in many transition countries especially at the outset of the transition process. Moreover, its shareholders are sovereign and assigned to the bank the mission to foster and not crowd out financial flows towards the private sector in these countries. Our results yield two conclusions. First, they unambiguously identify the role of memory in the bank's lending decisions when the firms have signed more than one contract. Second, they confirm the relevance of the empirical method we propose to control for the adverse selection effect, which, to our opinion, explain the inconclusive results that is generally observed in the empirical literature. However, we think that these results will be hard to replicate with datasets from private banks.

\section{References}

[1] Baltagi, B. (2005): "Econometric Analysis of Panel Data", Wiley \& Son, 3rd edition.

[2] Baum, Ch. (2006):"An introduction to Modern Econometrics using Stata", STATA Press.

[3] Blackwell, D. W - Winters, D.B. (1997): "Banking relationship and the Effect of Monitoring on Loan Prices", Journal of Financial Research, vol.20, pp. 275-289.

[4] Berger, A.N. - Udell, G.F. (1995): "Relationship lending and Lines of Credit in Small Firm Finance", Journal of Business, vol. 68, pp. 351-381.

[5] Bodenhorn, H. (2003): "Short-term Loans and Long-Term Relationship: Relationship Lending in Early America", Journal of Money, Credit and Banking, vol.35, pp. 485505 ,

[6] Boot, A.W.A - Thakor, V. A. (1994): "Moral Hazard and Secured Lending in an Infinitely Repeated Credit Market Game", International Economic Review, vol.35(4), pp. 899-920,

[7] Chiappori, P.A. - Macho Stadler, I. (1990): "Contrats de travail répétés: le rôle de la mémoire", Annales d'économie et de statistiques, vol.17, pp. 47-70.

[8] Chiappori, P. A. - Macho Stadler, I.- Rey, P. - Salanié, B. (1994): " Repeated moral hazard: The role of memory, commitment, and the access to the credit markets", European Economic Review, vol.38, pp. 1527-1553. 
[9] Cole, R. A. (1998): "The Importance of Relationship to the Availability of Credit" Journal of Banking and Finance, vol.22, pp. 959-977.

[10] Degryse, H. - Cayseele van, P. (2000): "Relationship Lending within a Bank-Based System: Evidence from Small Business Data", Journal of Financial Intermediation, vol.9, pp. 90-109.

[11] Elsas, R. - Krahnen, J. P. (1998): "Is Relationship Lending Special ? Evidence from Credit-File Data in Germany" Journal of Banking and Finance, vol.22, pp. 1283-1316.

[12] EBRD (1999): Financing EBRD, London.

[13] EBRD (2004): Transition Report, London

[14] Ghatak, M. (1999): "Group lending, local information and peer selection", Journal of Development Economics, vol.60, pp. 27-50.

[15] Greenbaum, S.- Kanatas, G. - Venezia, I. (1989): "Equilibrium loan pricing under the bank client relationship", Journal of Banking and Finance, vol.13, pp. 221-235.

[16] Lambert, R.A.(1983): "Long-term contracts and moral hazard", The Bell Journal of Economics, vol.14 (2), pp.441-452.

[17] Macho-Stadler, I. - Pérez-Castrillo D. (2001): An Introduction to the Economics of Information. Incentives and Contracts, Second Edition, Oxford University Press.

[18] Petersen, M.A.- Rajan, R.G. (1998): "The Benefits of Lending Relationships: Evidence from Small Business Data", Journal of Finance, vol.50, pp. 1113-1146.

[19] Polity IV project (2007), www.cidcm.umd.edu/polity/

[20] Rogerson, W. (1985): "Repeated Moral Hazard", Econometrica, vol.53, pp. 69-76.

[21] Sharpe, S. (1990): "Asymmetric Information, Bank Lending and Implicit Contracts: A Stylized Model of Costumer Relationships", Journal of Finance, vol.45, pp. 1069-1087.

[22] Stiglitz, J.- Weiss, A. (1981): "Credit rationing in markets with imperfect information" American Economic Review, vo. 71(3), pp. 393-410.

[23] Stiglitz, J.- Weiss, A. (1983): "Incentives effects of terminations: Applications to the credit and labor markets" American Economic Review, vo. 73, pp. 912-927. 


\section{List of table}

Table 1: EBRD contracts and their frequency (1991-2003)

(Source: EBRD, Calculus: authors)

\begin{tabular}{|l|l|l|}
\hline Contract & Freq. & \% \\
\hline Debt & 1 & 0.06 \\
\hline Equity & 141 & 7.92 \\
\hline Guarantee & 100 & 5.62 \\
\hline Line of Credit & 7 & 0.39 \\
\hline Loan & 949 & 53.31 \\
\hline Loan/Line of credit & 1 & 0.06 \\
\hline Loan/Shares & 96 & 5.39 \\
\hline Loan/guarantee & 1 & 0.06 \\
\hline Senior debt & 72 & 4.04 \\
\hline Shares & 404 & 22.70 \\
\hline Shares/Loan & 2 & 0.11 \\
\hline Shares/Loan/Share & 1 & 0.06 \\
\hline Share/Loan/Guarantee & 1 & 0.06 \\
\hline Subordinated debt & 4 & 0.22 \\
\hline TOTAL & $\mathbf{1 7 8 0}$ & $\mathbf{1 0 0}$ \\
\hline
\end{tabular}

Table 2: Descriptive statistics on loans (value $€$ mill. ) (Source: EBRD, Calculus: authors)

\begin{tabular}{|llllllll|}
\hline & Variable & Obs & Mean & Std. Dev & Median & Min & Max \\
\hline Total sample $^{9}$ & & & & & & & \\
& Bank financing & 945 & 21.25 & 27.76 & 12.7 & 0.1 & 233.76 \\
& Tot. project value & 936 & 60.81 & 109.94 & 29.25 & 0.1 & 923.9 \\
\hline Up to 1995 & & & & & & \\
& Bank financing & 219 & 19.98 & 23.53 & 10.90 & 0.2 & 142 \\
& Tot. project value & 220 & 68.24 & 115.81 & 31.85 & 0.5 & 923.9 \\
\hline From 2000 on & & & & & & \\
& Bank financing & 438 & 21.19 & 31.36 & 10.00 & 0.1 & 233.76 \\
& Tot. project value & 427 & 50.60 & 94.94 & 15.00 & 0.1 & 750 \\
\hline
\end{tabular}

\footnotetext{
${ }^{9}$ The difference between the number of observation in bank financing and total project value is due to lack of data for one of the two variables.
} 
Table 3: Descriptive statistics on shares (value $€$ mill.) (Source: EBRD, Calculus: authors)

\begin{tabular}{|llllllll|}
\hline & Variable & Obs & Mean & Std. Dev & Median & Min & Max \\
\hline Total sample & & & & & & & \\
& Bank financing & 402 & 9.05 & 13.93 & 3.2 & 0.1 & 125 \\
& Tot. project value & 402 & 34.57 & 76.98 & 8.2 & 0.1 & 1028.9 \\
\hline Up to 1995 & & & & & & \\
& Bank financing & 84 & 10.14 & 11.82 & 5.9 & 0.1 & 53.4 \\
& Tot. project value & 84 & 35.92 & 59.96 & 18.6 & 0.7 & 384.1 \\
\hline From 2000 on & & & & & & & \\
& Bank financing & 100 & 7.45 & 11.95 & 3.1 & 0.3 & 53.7 \\
& Tot. project value & 99 & 26.87 & 63.57 & 4.8 & 0.5 & 365.8 \\
\hline
\end{tabular}

Table 5: Descriptive statistics on several-contract firms (value $€$ mill. ) (Source: EBRD, Calculus: authors)

\begin{tabular}{|llllllll|}
\hline & Variable & Obs & Mean & Std. Dev & Median & Min & Max \\
\hline Total sample & & & & & & & \\
& Bank financing & 405 & 11.97 & 17.75 & 6.6 & 0.5 & 130 \\
& Tot. project value & 395 & 28.7 & 56.3 & 8.7 & 0.5 & 651.3 \\
\hline Up to 1995 & & & & & & \\
& Bank financing & 59 & 16.47 & 20.83 & 8.8 & 0.5 & 109.8 \\
& Tot. project value & 59 & 36.25 & 53.61 & 20.8 & 1.3 & 329.6 \\
\hline From 2000 on & & & & & & & \\
& Bank financing & 219 & 11.78 & 18.87 & 5.6 & 0.1 & 130 \\
& Tot. project value & 202 & 28.63 & 65.32 & 7.9 & 0.1 & 651.3 \\
\hline
\end{tabular}

Table 6: Descriptive statistics: cumulated investment by region (\%) (Source: EBRD, Calculus: authors)

\begin{tabular}{lrrr}
\hline Regions & $\mathbf{1 9 9 1 - 1 9 9 5}$ & $\mathbf{1 9 9 6 - 1 9 9 9}$ & $\mathbf{2 0 0 0 - 2 0 0 3}$ \\
\hline & & & \\
Russia & 19.9 & 29.1 & 28.8 \\
Central Europe and Baltic States & 45.9 & 32.9 & 36.0 \\
\hline Eastern Europe and the Caucasus & 11.8 & 11.9 & 7.5 \\
South-Eastern Europe & 16.8 & 13.5 & 20.5 \\
\hline Central Asia & 5.6 & 12.6 & 7.2 \\
\hline
\end{tabular}


Table 7: Descriptive statistics: cumulated investment by sector (\%) (Source: EBRD, Calculus: authors)

\begin{tabular}{lrrr}
\hline Sector & $\mathbf{1 9 9 1 - 1 9 9 5}$ & $\mathbf{1 9 9 6 - 1 9 9 9}$ & $\mathbf{2 0 0 0 - 2 0 0 3}$ \\
\hline & & & \\
Finance & 19.6 & 27.0 & 30.2 \\
Environment &.. & 4.1 &.. \\
\hline Food & 2.6 & 8.1 & 9.0 \\
Telecom & 14.5 & 6.8 & 4.9 \\
Energy & 9.5 & 9.7 & 8.9 \\
\hline Oil/Gas/Nat.Res. & 10.8 & 10.3 & 8.4 \\
Transport & 8.8 & 3.4 & 16.1 \\
Others & 34.3 & 30.6 & 22.4 \\
\hline
\end{tabular}

\section{BOX 1: LIST OF VARIABLES}

\begin{tabular}{|l|l|}
\hline Ct2 & Type of contract signed by the EBRD (13 possible contracts) \\
\hline DEM & Index of democraticlevel in the country hosting the investment (Polity IV, 2007) \\
\hline DI & Dummy variable for presence of a public client or other interests of the bank in the project \\
\hline DSY & Dummy for investments financed by the EBRD for the same firm in the same year \\
\hline GDP & Gross domestic product per-capita of the host country (IMF statistics, 2007) \\
\hline IP & Total value of the investment project \\
\hline IPDSY & Value of projects for firms obtaining more than one credit the same year \\
\hline IV & Value of the investment financed by the EBRD \\
\hline Libor & Average annual value of Libor interest rate at 12 months. \\
\hline PPRR & Dummy for the first contract signed by the EBRD with firms obtaining more than one credit \\
\hline Sector & Dummy by sector \\
\hline Year & Time dummy \\
\hline Ct2PPRR & Interaction term between Ct2 and PPPRR \\
\hline Ct2IPPRR & Interaction term among Ct2, IP and PPPRR \\
\hline IPPPPRR & Interaction term between IP and PPPRR \\
\hline
\end{tabular}


Table 8: Descriptive statistics

\begin{tabular}{|c|c|c|c|c|c|c|}
\hline & Variable & Obs & Mean & Std. Dev & Min & Max \\
\hline \multicolumn{7}{|c|}{ Sample } \\
\hline & Libor & 1788 & 4.23 & 1.45 & 2.17 & 9.91 \\
\hline & GDP per-capita $(\$)$ & 1706 & 2706.5 & 2143.6 & 151.48 & 13937.4 \\
\hline & Polity IV index (DEM) & 1662 & 6.5 & 2.85 & 0 & 10 \\
\hline & EBRD Credit Value (€ mill. ) & 1766 & 16.5 & 24.2 & 0 & 233.7 \\
\hline & Total project value (€ mill. ) & 1750 & 49.23 & 97.87 & 0 & 1028.9 \\
\hline & Financing share & 1728 & 0.6 & 0.33 & 0.009 & 1 \\
\hline \multicolumn{7}{|l|}{1993} \\
\hline & Libor & 71 & 7.24 & 0 & 7.24 & 7.24 \\
\hline & GDP per-capita $(\$)$ & 68 & 2167 & 1519.7 & 225.8 & 6801.8 \\
\hline & Polity IV index (DEM) & 68 & 7.32 & 2.45 & 0 & 10 \\
\hline & EBRD Credit Value (€ mill.) & 71 & 20.36 & 23.9 & 0.1 & 100.12 \\
\hline & Total project value (€ mill.) & 71 & 69.98 & 96.95 & 1.3 & 464.7 \\
\hline & Financing share & 71 & 0.43 & 0.28 & 0.04 & 1 \\
\hline \multicolumn{7}{|l|}{2003} \\
\hline & Libor & 272 & 2.17 & 0 & 2.17 & 2.17 \\
\hline & GDP per-capita $(\$)$ & 260 & 3292.8 & 2539.6 & 248.2 & 13937.4 \\
\hline & Polity IV index (DEM) & 254 & 6.61 & 3.04 & 0 & 10 \\
\hline & EBRD Credit Value (€ mill.) & 270 & 13.69 & 23.7 & 0.1 & 230.2 \\
\hline & Total project value(€ mill.) & 271 & 33.26 & 77.4 & 0.1 & 750 \\
\hline & Financing share & 270 & 0.69 & 0.34 & 0.01 & 1 \\
\hline
\end{tabular}


Table 9

Econometric results: One-contract firms

Method of estimation: Pooled OLS, Value in brackets: Std Error, Dependent varibale : IV

\begin{tabular}{|c|c|c|}
\hline & OLS & OLS \\
\hline C & $14.75(6.9)^{* *}$ & $8.38(7.56)$ \\
\hline IP & $0.15(0.02)^{* * *}$ & $0.15(0.02)^{* * *}$ \\
\hline DI & $8.12(2.71)^{* * *}$ & $8.00(2.75)^{* * *}$ \\
\hline Dem & $-0.21(0.19)$ & dropped \\
\hline Libor & $-1.78(0.73)^{* *}$ & $0.32(0.92)$ \\
\hline GDP & $0.0004(0.0003)$ & $0.0004(0.0003)$ \\
\hline Dummy years & yes & yes \\
\hline Dummy sectors & yes & yes \\
\hline DEM*years & no & yes \\
\hline \multicolumn{3}{|l|}{ Tests: } \\
\hline D. Years $=0$ & $2.61^{* * *}$ & 0.89 \\
\hline D. Sectors $=0$ & $4.47^{* * *}$ & $3.20^{* * *}$ \\
\hline DEM $^{*}$ year $=0$ & & $1.55^{*}$ \\
\hline \multicolumn{3}{|l|}{ DEM*year=D. Years } \\
\hline Robustness errors & Heterosk. & Heterosk \\
\hline Adj. R-Square & 0.51 & 0.51 \\
\hline OBS & 1269 & 1269 \\
\hline
\end{tabular}


Table 10

Econometric results: One-contract firms

Method of estimation: Fixed effects, Value in brackets: Std Error, Dependent varibale : IV

\begin{tabular}{|c|c|c|}
\hline & Fixed effects & Fixed effects \\
\hline $\mathrm{C}$ & $14.7(6.77)^{* *}$ & $-8.78(-0.57)$ \\
\hline IP & $0.16(0.02)^{* * *}$ & $0.15(0.006)^{* * *}$ \\
\hline DI & $7.19(2.72)^{* * *}$ & $7.12(2.04)^{* * *}$ \\
\hline Dem & $-0.14(0.19)$ & dropped \\
\hline Libor & $-2.03(0.70)^{* * *}$ & $3.94(2.82)$ \\
\hline GDP & $0.0005(0.0003)$ & $0.0004(0.0003)$ \\
\hline Dummy years & yes & yes \\
\hline Dummy sectors & yes & yes \\
\hline DEM*years & no & yes \\
\hline Fixed effects & $\mathrm{Ct} 2$ & $\mathrm{Ct} 2$ \\
\hline \multicolumn{3}{|l|}{ Tests: } \\
\hline Hausman Test $\left(\chi^{2}\right)$ & $11.20^{* *}$ & $17.18^{* * *}$ \\
\hline F-test: fixed vs pooled & $4.33^{* * *}$ & $4.57^{* * *}$ \\
\hline D. Years $=0$ & $3.03^{* * *}$ & 0.98 \\
\hline D. Sectors $=0$ & $2.02^{* * *}$ & $1.73^{* *}$ \\
\hline $\mathrm{DEM}^{*}$ year $=0$ & & $1.82^{* *}$ \\
\hline $\boldsymbol{\sigma}_{u}$ & 27.75 & 28.63 \\
\hline$\rho$ & 0.70 & 0.71 \\
\hline Robustness errors & Heterosk. & Heterosk \\
\hline R-Square (within) & 0.48 & 0.49 \\
\hline OBS & 1265 & 1265 \\
\hline Groups & 13 & 13 \\
\hline
\end{tabular}




\section{Table 11}

Econometric results: several-contract firms

Method of estimation: Pooled OLS (with error correction), Value in brackets: Std Error, Dependent varibale : IV

\begin{tabular}{|c|c|c|c|}
\hline & OLS & OLS & OLS \\
\hline $\mathrm{C}$ & $14.57(10.14)$ & $0.44(3.65)$ & $14.57(7.34)^{* *}$ \\
\hline IP & $0.21(0.03)^{* * *}$ & $0.21(0.03)^{* * *}$ & $0.22(0.032)^{* * *}$ \\
\hline DI & $1.96(4.11)$ & $1.97(4.06)$ & $1.96(0.62)$ \\
\hline Dem & dropped & $-0.19(0.19)$ & dropped \\
\hline Libor & $-5.58(4.42)$ & $0.67(1.18)$ & $-5.58(3.04)^{*}$ \\
\hline GDP & $0.0007(0.0004)^{*}$ & $0.0007(0.0004)^{* *}$ & $0.0007(0.0004)^{*}$ \\
\hline IPDSY & $0.34(0.12)^{* * *}$ & $0.32(0.11)^{* * *}$ & $0.34(0.12)^{* * *}$ \\
\hline Dummy years & yes & yes & yes \\
\hline Dummy sectors & yes & yes & yes \\
\hline DEM*years & yes & no & yes \\
\hline \multicolumn{4}{|l|}{ Tests: } \\
\hline D. Years $=0$ & $1.81^{*}$ & 0.69 & $2.07^{* *}$ \\
\hline D. Sectors $=0$ & $3.30^{* * *}$ & $4.20 * * *$ & $2.99^{* * *}$ \\
\hline DEM $^{*}$ year $=0$ & 1.52 & & $2.16^{* *}$ \\
\hline DEM $^{*}$ year $=$ D. Years & & & $3.06^{* * *}$ \\
\hline Robustness errors & Heterosk & Heterosk & Cluster \\
\hline Adj. R-Square & 0.65 & 0.64 & 0.65 \\
\hline OBS & 346 & 346 & 346 \\
\hline
\end{tabular}


Table 12

Econometric results: several-contract firms

Method of estimation: Fixed effects (with error correction ), Value in brackets: Std Error, Dependent varibale : IV

\begin{tabular}{|c|c|c|c|}
\hline & Fixed effects & Fixed effects & Fixed effects \\
\hline C & $1.43(10.39)$ & $-2.84(4.95)$ & $13.43(7.60)^{*}$ \\
\hline IP & $0.21(0.03)^{* * *}$ & $0.21(0.03)^{* * *}$ & $0.21(0.03)^{* * *}$ \\
\hline DI & $1.14(4.57)$ & $1.37(4.50)$ & $1.14(4.36)$ \\
\hline Dem & dropped & $-0.11(0.21)$ & dropped \\
\hline Libor & $-5.34(4.43)$ & $0.85(1.22)$ & $-5.34(3.04)^{*}$ \\
\hline GDP & $0.0009(0.0004)^{* *}$ & $0.001(0.0004)^{* *}$ & $0.0009\left(0.0004^{*}\right)$ \\
\hline IPDSY & $0.34(0.12)^{* * *}$ & $0.32(0.11)^{* * *}$ & $0.34(0.11)^{* * *}$ \\
\hline Dummy years & yes & yes & yes \\
\hline Dummy sectors & yes & yes & yes \\
\hline DEM*years & yes & no & yes \\
\hline Fixed effects & ct2 & ct2 & ct2 \\
\hline \multicolumn{4}{|l|}{ Tests: } \\
\hline Hausman Test $\left(\chi^{2}\right)$ & $18.32^{* * *}$ & & \\
\hline F-test: fixed vs pooled & $1.85^{*}$ & 1.65 & \\
\hline D. Years $=0$ & $1.7^{*}$ & 0.51 & $2.05^{* *}$ \\
\hline D. Sectors $=0$ & $3.15^{* * *}$ & $4.42^{* * *}$ & $3.22^{* * *}$ \\
\hline $\mathrm{DEM}^{*}$ year $=0$ & $1.68^{*}$ & & $2.42^{* * *}$ \\
\hline DEM$^{*}$ year $=$ D. Years & 1.49 & & $2.81^{* * *}$ \\
\hline $\boldsymbol{\sigma}_{u}$ & 4.21 & 3.20 & 4.21 \\
\hline$\rho$ & 0.12 & 0.07 & 0.12 \\
\hline Robustness errors & Heterosk. & Heterosk & Cluster \\
\hline R-Square (within) & 0.48 & 0.64 & 0.65 \\
\hline OBS & 344 & 344 & 344 \\
\hline Groups & 8 & 8 & 8 \\
\hline
\end{tabular}

*** $1 \%$ significance level; ** 5\%; * $10 \%$ 


\section{Table 13}

Econometric results: several-contract firms

Method of estimation: Fixed effects (with error correction), Value in brackets: Std Error, Dependent varibale : IV

\begin{tabular}{|c|c|c|}
\hline & Fixed effects & Fixed effects \\
\hline C & $23.13(6.68)^{* * *}$ & $23.13(5.44)^{* * *}$ \\
\hline IP & $0.19(0.03)^{* * *}$ & $0.19(0.03)^{* * *}$ \\
\hline DI & $-2.08(5.59)$ & $-2.08(4.45)$ \\
\hline Dem & dropped & dropped \\
\hline Libor & $-9.08(2.01)^{* * *}$ & $-9.08(1.6)^{* * *}$ \\
\hline GDP & $0.0008(0.0006)$ & $0.0008(0.0006)$ \\
\hline IPDSY & $0.40(0.14)^{* * *}$ & $0.40(0.12)^{* * *}$ \\
\hline Dummy years & yes & yes \\
\hline Dummy sectors & yes & yes \\
\hline DEM*years & yes & yes \\
\hline Fixed effects & IPPPRR & IPPPRR \\
\hline \multicolumn{3}{|l|}{ Tests: } \\
\hline Hausman Test $\left(\chi^{2}\right)$ & $91.33^{* * *}$ & \\
\hline F-test: fixed vs pooled & $1.52^{* * *}$ & \\
\hline D. Years $=0$ & $6.59^{* * *}$ & $6.59^{* * *}$ \\
\hline D. Sectors $=0$ & $1.65^{*}$ & $1.65^{*}$ \\
\hline DEM $*$ year $=0$ & $22.66^{* * *}$ & $22.66^{* * *}$ \\
\hline DEM $*$ year =D. Years & $24.51^{* * *}$ & $24.51^{* * *}$ \\
\hline$\overline{\sigma_{u}}$ & 14.55 & 14.55 \\
\hline$\rho$ & 0.65 & 0.65 \\
\hline Robustness errors & Heterosk. & Cluster \\
\hline Adj. R-Square & 0.66 & 0.66 \\
\hline OBS & 346 & 346 \\
\hline Groups & 90 & 90 \\
\hline
\end{tabular}




\section{Table 14}

Econometric results: several-contract firms

Method of estimation: Fixed effects (with error correction), Value in brackets: Std Error, Dependent varibale : IV

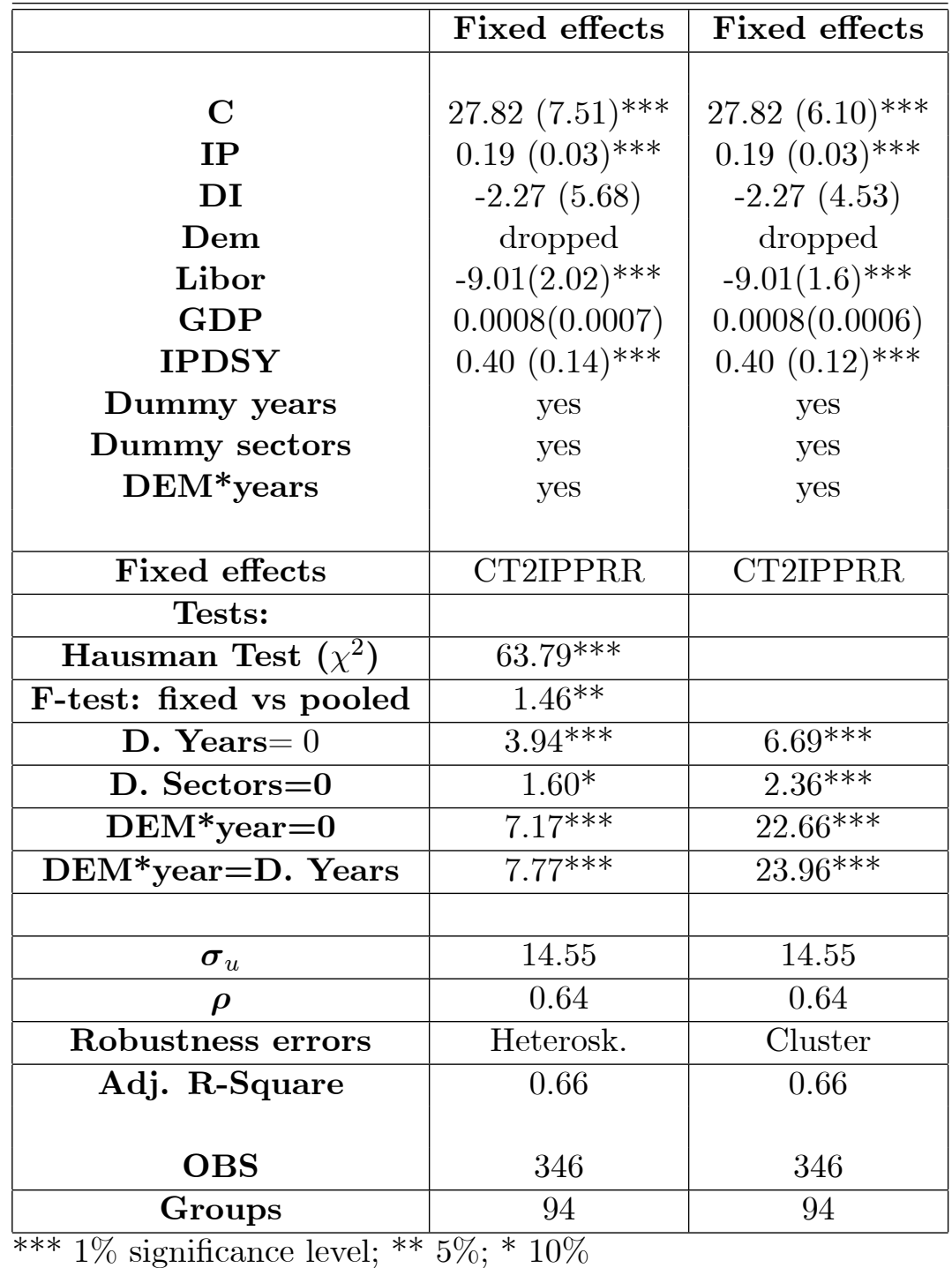




\section{Table 15}

Econometric results: several-contract firms

Method of estimation: Fixed effects (with error correction), Value in brackets: Std Error, Dependent varibale : IV

\begin{tabular}{|c|c|c|}
\hline & Fixed effects & Fixed effects \\
\hline C & $22.51(9.04)^{* *}$ & $22.51(7.00)^{* *}$ \\
\hline IP & $0.21(0.03)^{* * *}$ & $0.21(0.03)^{* * *}$ \\
\hline DI & $1.11(4.03)$ & $1.11(3.87)$ \\
\hline Dem & dropped & dropped \\
\hline Libor & $-6.40(3.68)^{*}$ & $-6.40(2.65)^{* *}$ \\
\hline GDP & $0.0008(0.0004)^{*}$ & $0.0008(0.0004)^{*}$ \\
\hline IPDSY & $0.38(0.12)^{* * *}$ & $0.38(0.12)^{* * *}$ \\
\hline Dummy years & yes & yes \\
\hline Dummy sectors & yes & yes \\
\hline DEM*years & yes & yes \\
\hline Fixed effects & CT2PPRR & CT2PPRR \\
\hline \multicolumn{3}{|l|}{ Tests: } \\
\hline Hausman Test $\left(\chi^{2}\right)$ & na ${ }^{10}$ & \\
\hline F-test: fixed vs pooled & $2.73^{*}$ & \\
\hline D. Years $=0$ & $2.27^{* *}$ & $2.73^{* * *}$ \\
\hline D. Sectors $=0$ & $3.09^{* * *}$ & $2.80^{* * *}$ \\
\hline $\mathrm{DEM}^{*}$ year $=0$ & $1.93^{* *}$ & $3.02^{* * *}$ \\
\hline DEM*year=D. Years & $2.11^{* *}$ & $4.30^{* * *}$ \\
\hline $\boldsymbol{\sigma}_{u}$ & 5.51 & 5.51 \\
\hline$\rho$ & 0.19 & 0.19 \\
\hline Robustness errors & Heterosk & Cluster \\
\hline Adj. R-Square & 0.66 & 0.66 \\
\hline OBS & 346 & 346 \\
\hline Groups & 8 & 8 \\
\hline
\end{tabular}

\footnotetext{
${ }^{10}$ We experience problems in running this test with this fixed effect either in the current and the reduced form. The variable (CT2PPRR) contain a big mass of zero values and, hence, the model fitted fails to meet the asympothic assumption of the Hausman test.
} 


\section{A List of sectors}

The following table gather all the sectors firms asking for a financement belong to:

Bank, Finance and holding

Chemical (includ. Pharmacy)

Education and other public services

Electrictronical and Hi-Tech

Energy

Environment

Food and beverage (incl. agriculture)

Health and personal care

Hotels and tourism

Infrastructure (transport)
Local servicies (water, waste...)

Media

Manufacturing

Metal

Natural resources

Oil and gas

Real estates

Telecommunication

Trade and retails

Vehicles 